\title{
The Issue of Applying Professional Values in Social Work ${ }^{1}$
}

\section{Monika Flídrová}

The issue of the values of social work is at present a frequent subject of studies, in which values are discussed often in an effort to anchor professional identity. ${ }^{2}$ This close link between values and professional identity follows already from general facts, i.e., that the applied values of social work co-participate in forming a stable identity of the profession, since through their realization the principles, goals of the profession as well as goals of the individual organizations issuing from values are fulfilled. Values affect the choice of methods, form relationships especially between worker and client, or also define the profession's mission. Intelligible definition of values therefore contributes to greater transparency of the profession for its clients and the broad public, which can as a result imagine the purpose and goal of the work more easily. "A social worker therefore does not need only knowledge and skills why and how to do social work, but also values so that in performing social work he can make correct decisions. If value relativism held, social work would be meaningless. When everything can be correct and incorrect, good and bad, and it only depends on the point of view, points of departure, cultural stereotypes, then there is no point trying to change a life situation. Then it is not necessary to help another person to make his life (again) better or maintain its high quality." ${ }^{4}$

The professional values of social work are therefore defined in the ethical codes of individual companies or organizations ${ }^{5}$ (e.g. in mission statements), but also in many authors. ${ }^{6}$ Paradoxically, we are thus finally presented with a broad spectrum of professional values. The resulting plurality in defining particular values can be due to many factors, of which let us now mention e.g. the issue of defining the concept of value, the undefined boundaries of professional ethics and the related as well as lacking clear idea of what values ought to be included in social work. We thus enter a vicious cycle leading (1) from the issue of professional values (2) to vague professional identity (3) and to insufficient application of values in practice. (4) As a result the essence of the profession is not being fulfilled, (5) which should lead us to reflection on defining basic professional values. The main intention of this study is therefore first of all to point out the uneasy application of values in practice by describing some causes or barriers preventing social workers from applying professional

\footnotetext{
1 This study is an output of the project research of the Grant Agency of the University of South Bohemia 117/2013/H

- Conception of quality of social work in connection with self-definition of the social worker and his helping profession.

2 Cf. e.g. Monika FLÍDROVÁ - Michal OPATRNÝ, Role hodnot videntitě sociální práce, Sociální práce / Sociálna práca 2/2014, pp. 118-126.

3 Cf. ibid, pp. 123-125; Mirka NEČASOVÁ, Profesní etika, in: Metody a ř́zení sociální práce, ed. Oldřich MATOUŠEK, Praha: Portál, 2013, p. 32.

4 Monika FLÍDROVÁ - Michal OPATRNÝ, Role hodnot v identitě sociální práce, p. 122.

5 Cf. e.g. (C) British Association of Social Workers, The Code of Ethics for Social Work (online), at: http://cdn.basw.co.uk/upload/ basw_112315-7.pdf, retrieved December 12 2014.

6 Cf. e.g. Sarah BANKS, The social work value base: human rights and social justice in talk and action, in: The Value Base of Social Work and Social Care: An Active Learning Handbook, ed. Adam BERNARD - Nigel HORNER, Berkshire: Open University Press, 2008, p. 31. From the German speaking world let us mention e.g. Silvia Staub-Bernasconi, who bases the value concept of social work on human rights, starting not from values but from universal human needs. Cf. Silvia STAUB-BERNASCONI, Soziale Arbeit als Handlungswissenschaft: systemtheoretische Grundlagen und professionelle Praxis - ein Lebrbuch, Bern; Stuttgart; Wien: Haupt, 2007, pp. 192-193.
} 
values in practice. In the study we draw on current discussions on values in the ethics of social work, which is also why the causes of uneasy application of values identified below by far do not offer the reader a complete list. The goal is rather to contribute to the broad discussion dealing with the significance and issue of values in social work. ${ }^{7}$

\section{Knowing professional values}

As part of project no. 117/2013/H at the Department of Ethics, Psychology and Charity Work at the Faculty of Theology, University of South Bohemia, investigating the "conception of quality of social work in connection with self-definition of the social worker and his helping profession", pre-research was realized in 2013by the qualitative method of structured interview with open questions, with the goal of mapping social workers' subjective view of social work, its quality and position in society. The research unit was constituted by 25 social workers selected based on demographic data according to the selection method, ${ }^{8}$ who met the conditions of education according to Law 108/2006 Sb. ${ }^{9}$ and had at least two years of practice in the field. One of the research questions asked "what values are connected with the profession of social worker."

While the International Federation of Social Workers included values such as dignity, human rights and social justice in the International Ethical Code ${ }^{10}$ and the Association of Social Workers in CR mentioned democracy, human rights and social justice in the Ethical Code of the Association of Social Workers of CR (whereby both codes also focus at expertise), ${ }^{11}$ the "value" most often cited by social workers (research respondents) was empathy. This "value" was mentioned fifteen times (i.e., by 3/5 of the respondent). Other "values" were rarely mentioned. Only six workers mentioned expertise. The values humanity, relationship, service and altruism appeared five times in the respondents' enumeration. The principal values of ethical codes were hardly mentioned. Though we can generally associate the value of dignity with the value of humanity or respect, it did not appear in any respondent's enumeration as such. Only one social worker mentioned human rights, three others at least mentioned equality or non-discrimination, i.e., individual principles of human rights. Only one respondent cited the value of social justice, which is a primarily acknowledged value of social work not only in the codes. On the other hand, social workers often focused on "values" describing the character of the worker. According to them a social worker ought to be a mature personality, which they associated with trustworthiness; he ought to be open,

\footnotetext{
7 S. Banks identifies precisely also insufficient communication among different types of workers and organizations as one of the barriers to applying professional values in practice. Cf. Sarah BANKS, The social work value base, p. 32.

8 Respondents were selected using the method of nonrandom intentional selection (cf. Jan HENDL, Kvalitativní výzkum, Praha: Portál, 2005, p. 52) from all regions of the Czech Republic, types of municipality (municipality, town, city) and social services (ambulant, residential, terrain, office). The selection considered three aspects: proportion of individual types of facility in state, proportion of individual facilities according to the number of inhabitants of the fourteen regions and within them according to the size of domicile.

9 Cf. Law no. 108/2006 Sb., on social services, $\mathbb{S} 110$.

10 Cf. (C) Společnost sociálních pracovníků ČR, Etika sociální práce-principy (on-line), at: http://socialnipracovnici.cz/public/ upload/image/mezinarodni_eticky_kodex.pdf, retrieved December 12 2014.

11 Cf. (C) Společnost sociálních pracovníků ČR, Etický kodex společnosti sociálních pracovníkủ ČR (on-line), at: http:// socialnipracovnici.cz/public/upload/image/eticky_kodex_sspcr.pdf, retrieved December 12 2014.
} 
helpful to clients or honest, etc. Only two social workers out of 25 mentioned the value of solidarity, it was cited as frequently as the values of family and truth. ${ }^{12}$

The professional values mentioned by the social workers taking part in the research contribute to opening the topic of the issue of applying professional values and seeking causes that appear to be multifactorial. The evaluation of answers has shown first of all (1) a lack of knowledge of values cited in codes or by professional experts, but also (2) construing the concept of value rather in the context of personality traits and competences (especially communication skills) needed for performing the profession (i.e., a misunderstanding of the concept of value) and (3) a significant impact of personal values (e.g. love, truth) on forming the conception of the profession. That is why personal values in conflict with professional values can be one of the causes of not applying values in practice (see point 4). We can also ask whether the attitude of many social workers is not too lax, whether their practice takes sufficient account of the mission and organization goals, or whether their acting and procedures are not rather motivated by philanthropy, without effort at a professional conception of social work.

\section{Ambiguous definition of concept}

One of the main causes of the lack of knowledge of the professional values of social work, as well as general value pluralism, is unintelligibility of the concept of value. Although values are a frequent concept in the humanities, they are not univocally defined in psychology, philosophy or sociology. ${ }^{13}$ As a result many definitions and classifications of values arise, leading to a very vague conception of them. That is also why defining the concept of value in the context of social work is as yet a primary problem of professional ethics. ${ }^{14}$ In other words, a formulation of the conception of value in the context of social work would make it possible to define professional values more univocally, then interiorize them and apply to practice.

The ambiguity of the concept is also manifest in the International Ethical Code, which uses the concept "principle" instead of "value". In general these two concepts often occur as synonymous in the literature. But in the Code these principles are elaborated into further principles. Human rights also have a double position in the Code: First they occur in the position of a basic mentioned value and then they "follow" from the value and dignity of all people. ${ }^{15}$ We can therefore ask whether we can regard human rights as a professional value of social work. If we incline to defining the concept of value based on its properties, then one of the attributes of value, its universality, ranks values above norms and principles. ${ }^{16}$ That is why human rights should also be regarded rather as a set of principles, not labelled as professional value but deriving from values. To speak of professional values among social

12 More detailed elaboration of the research question see Monika FLÍDROVÁ, Sociální práce jako práce rízená profesními hodnotami (diploma thesis), České Budějovice: Faculty of Theology, University of South Bohemia, 2014.

13 Cf. e.g. Panajotis CAKIRPALOGLU, Psychologie hodnot, Olomouc: Votobia, 2004; Ivan BLECHA et al., Filosofický slovník,

Olomouc: Nakladatelství Olomouc, 1998, p. 171; Pavel KLENER - Miloslav PETRUSEK, Velký sociologický slovník I, Praha:

Karolinum, 1996, pp. 375-377.

14 Cf. Tomáš MACHULA - Helena MACHULOVÁ, Nedostatečná definice pojmu hodnota jako zásadní problém etiky sociální

práce, Sociální práce /Sociálna práca 1/2009, pp. 97-104.

15 Cf. (C) Společnost sociálních pracovníků ČR, Etika sociální práce - principy, art. 4.

16 Cf. Panajotis CAKIRPALOGLU, Psychologie hodnot, p. 364. 
workers without a consonant pre-understanding of the concept of value appears no longer tenable. We can also no longer make do in social work with a definition of value representing "what a given society and individual regard as desirable, appropriate and good - what they strive for" ${ }^{17}$ Although in social work we let ourselves be inspired by or take over some information from related fields, we need to define value in the profession ourselves not as "a general concept for everything we value or respect". ${ }^{18}$ The aim of own definition of the concept of value should be first of all the effort to construct own self-conception, identity, with the goal of structuring the position of values in the hierarchy of professional principles, goals or methods, so that the stability of the profession is reinforced, since it derives also from the set firm foundations (mission, values, and others) together with forming a hierarchy among them. ${ }^{19}$

\section{Plurality of professional values}

But in such procedure we will sooner or later reach the claim that social work can never be fully detached from the social environment in which it is realized, because it responds to its specific needs. Social work is therefore specific in that in connection with the variety of needs, cultures, thought, impact of religion etc. the view of the position of the individual professional values in social work partially changes. ${ }^{20}$ We can therefore not perceive value pluralism only negatively. Social work, responding to the pressing social problems of its time and milieu, essentially needs to be also partially flexible and varied, since "while overt enclosure and circumscription of the profession creates stability (whether by strictly defined and observed values), it does not facilitate growth, development and creativity." ${ }^{21}$ Banks further notes that uniformly defined values would be influenced primarily by Western European culture and thought, which does not comprise the entire spectrum of social work and need not be objectively most suitable for social work in all its extent. ${ }^{22}$ But on the other hand, overt openness of the profession and lack of circumscription (i.e., also within the defined values) lead to its vague identity or even "fragmentation". ${ }^{23}$

A partial solution to the conflict between strictly given professional values on the one hand and on the other hand professional values defined only within the individual organizations, associations, states, depending on the specificities of own culture and politics, may be offered precisely by professional ethical codes at the international level. At present the International Code binds (only) member organizations to the "...duty to develop and regularly update its own ethical norms or ethical guidelines so that they are consistent with the statement" 24 of the International Federation of Social Workers. But the International Ethical Code at the same time assumes that professional values mentioned in the Code will be developed

17 Oldřich MATOUŠEK, Slovník sociální práce, p. 77.

18 Radoslav GOLDMANN - Martina CICHÁ, Etika zdravotní a sociální práce, Olomouc: Univerzita Palackého, 2004, p. 8

19 Cf. Monika FLÍDROVÁ - Michal OPATRNÝ, Role hodnot v identitě sociální práce, p. 125.

20 Cf. Payne in Oldřich MATOUŠEK, Úvod: Cíle a úrovně sociální práce, in: Metody a řízení sociální práce, ed. Oldřich

MATOUŠEK, Praha: Portál, 2013, p. 12.

21 Monika FLÍDROVÁ - Michal OPATRNÝ, Role hodnot v identitě sociální práce, p. 125.

22 Cf. Sarah BANKS, The social work value base, p. 32.

23 Cf. Libor MUSIL, Různorodost pojetí, nejasná nabídka a kontrola výkonu „sociální práce“, Sociální práce /Sociálna práca 2/2008, pp. 83-84.

24 Cf. (C) Společnost sociálních pracovníků ČR, Etika sociální práce-principy, art. 5. 
according to own specificities, but remain in accord with it. ${ }^{25}$ But in the individual codes of member countries, associations and organizations we often lack a link or any reference to stipulated international professional values. ${ }^{26}$ We can ask to what extent the ambiguity of values is an important factor or to what extent it is a matter of insufficient involvement and lack of communication between social workers at international level.

Nonetheless, this specification of values can enable social workers to understand their importance and their interconnection with the profession's or organization's mission. That is why the process of applying professional values can to a great extent be influenced by the strategy of organization management. ${ }^{27}$ Interpretation of defined values also frequently appears abroad as well as in Czech literature (see Introduction). We can find a comprehensive elaboration of some values e.g. in the Encyclopaedia of Social Work, in which these values are presented rather in their historical context of Western European thought. In defining them the authors draw on political science, sociology, philosophy or ethics. But the individual values are insufficiently elaborated in the context of practice, principles and goals of social work. ${ }^{28}$ Continuous updating and interpretation of professional values often occurs in confrontation with an opposition attitude. Recall e.g. the broad discussion that began after the publication of M. Mitlöhner's article On the Legal and Etbical Problems Connected with the Birth of a Gravely Malformed Individual, ${ }^{29}$ whose different conception of humanity, dignity, freedom or meaning of life led in much to opening a debate on values. ${ }^{30}$

\section{Conflict of personal and professional values}

Nevertheless, it is a duty of professional ethics to incessantly react, respond, defend or update its value conception. But excessive effort to firmly define and apply professional values in social work is opposed by emphasis on conscience and own ethical acting of social workers based on personal values. ${ }^{31}$ That is why even "a code cannot be an exact recipe book according to which the social worker would act thoughtlessly - he would thus have no space for own judgment and deliberation and the ethical dimension would

\footnotetext{
25 Cf. ibid.

26 Comprehensive comparison of the ethical codes of different countries bas already been undertaken by S. Banks (cf. Sarab BANKS, Ethics and Values in Social Work, London: Macmillan Press, 1995, pp. 91-102).

27 One way of applying values in an organization is described by P. Vrzáček. In his proposal deriving from the practice of Home of the Elderly in Lanškroun he ascribes to organization the power to grasp and control the action of social workers based on values: "The organization must have a formulated vision and values that facilitate fulfilling the vision. The organization vision and values must be interconnected. Organization values must be defined in internal documentation, which must in various forms be accessible to all employees. Employees must know the organization values and must be able to fulfil their work duties in accordance with the organization values. Employees who adhere to the organization values in their work must be rewarded for that activity. Employees who do not adhere to the organization values must on the other hand be punished. All employees must supervise adherence to organization values, especially employees in managerial positions. Solving conflict situations pertains to managers." Petr VRZÁČEK, Vedení ve shodě s organizačními hodnotami, in: Hodnoty v prostředí sociálních a zdravotních služeb, ed. Zuzana HAVRDOVÁ, Praha: Fakulta humanitních studií Univerzity Karlovy, 2010, pp. 189-190.

28 Cf. e.g. Alois KŘIŠŤAN, Humanita; Tomáš MACHULA, Solidarita; Tomáš MACHULA, Důstojnost; Eva DRAGOMIRECKÁ,

Kvalita života, in: Encyklopedie sociální práce, ed. Oldřich MATOUŠEK, Praha: Portál, 2013, pp. 201-206, 223-226.

29 Cf. Miroslav MITLÖHNER, K právním a etickým problémům spojeným s narozením těžce malformovaného jedince, Časopis zdravotnickébo práva a bioetiky 1/2014, pp. 48-54.

30 The journal Caritas et veritas (1/2015) published by Faculty of Theology, University of South Bohemia, also thematically entered this discussion. The issue was entitled Right to Life and the papers in it directly or indirectly referred to Mitlöhner's text. 31 Cf. Frederic G. REAMER, Social work values and ethics, New York: Columbia university press, 1999, p. 28.
} 


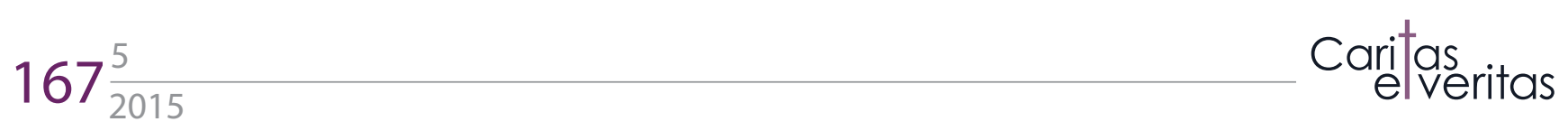

necessarily disappear from his acting." ${ }^{32}$ Personal values then prevent the social worker from approaching the profession mechanically, but enable him to perceive it as a personal mission and form relationships with clients based on the principle of genuineness, empathic understanding or sincerity. That is why a major part of research involving values in social work focuses on the personal values of social workers, because it is generally believed that precisely they have primary impact on his relationship to client, intervention methods and work procedures.

But projecting personal values into professional visions can be problematic. Values in general are an ideal, a universal notion of what is desirable (see point 2). Although social work does not exclude personal value and ethical orientations of worker in solving situations, which Reamer ${ }^{33}$ or Musil ${ }^{34}$ have dealt with, in fact these primarily affect the practice, stipulating basic professional values cannot be based only on own value orientations of social workers and their professional conception. The individual types of professional conception according to Reamer or Musil are rather a set of characteristics of types of social workers, i.e., what "material" is in fact available in social work. But then according to the survey (see point 1) the main value of social work should be empathy, which however is no professional ideal; it is normally designated only as a suitable communication skill, based on which e.g. the relationship between social worker and client is formed. ${ }^{35}$ But values ought to be closely interconnected with the professional vision, ${ }^{36}$ they are rather related to the meaning and mission of social work.

Nonetheless, personal values affect the very choice of the profession of social work. Hartl states that everyone who wants to devote himself to the profession ought to have the "basic personality traits of a social worker" even before embarking on the educational and work process in which the worker is responsible and obliged to act according to professional and specific organization values, if they are given by the organization. So whether a social worker is motivated by different values, he should first of all be able to reflect these values, i.e., be aware how they affect his activity and make use of it in an effort at a change for the better. $^{37}$

A social worker "must at the same time count with the fact that he will find himself in a tension between his personal values and the values of client, employer and in general the whole profession of social work. Thus certain value conflicts arise," 38 whose cause is a conflict of values in solving a particular problem. He can also get in conflict with a type of organization management, especially in those organizations in which emphasis is

\footnotetext{
32 Mirka NEČASOVÁ, Profesní etika, p. 42.

33 Reamer identified six models of ethical orientations of social workers that have appeared in the course of social work's development and are still present today side by side. Cf. Frederic G. REAMER, Social work values and ethics, pp. 17-18.

34 Musil specified four conceptions of social work (administrative, philanthropic, professional, activist) based especially on his research with social workers, investigating their value orientations and notions concerning their profession. Cf. Libor MUSIL, Různorodost pojetí, nejasná nabídka a kontrola výkonu „sociální práce“; Daniela RŮŽIČKOVÁ - Libor MUSIL, Hledají sociální pracovníci kolektivní identitu?, Sociální práce / Sociálna práca 3/2009, pp. 79-92.

35 Cf. Oldřich MATOUŠEK - Pavel HARTL, Nároky sociální práce a syndrom vyhoření, in: Metody a řízení sociální práce,

ed. Oldřich MATOUŠEK, Praha: Portál, 2013, pp. 51-52.

36 Cf. Petr VRZÁČEK, Vedení ve shodě s organizačními hodnotami, pp. 189-190.

37 Cf. Pavel HARTL, Poradenství, in: Metody a ř́zení sociální práce, ed. Oldřich MATOUŠEK, Praha: Portál, 2013 , p. 111.

38 Monika FLÍDROVÁ - Michal OPATRNYY, Role hodnot v identitě sociální práce, p. 122.
} 
placed on clearly defined rules and there is a clearly determined hierarchy together with the individual workers' competences: "Social workers employed in 'mechanical' bureaucratic organizations have less chance of professional autonomy then their colleagues working in smaller independent or private organizations. They also have lesser space for maintaining the ethical code as the primary obligation of the profession." ${ }^{39}$ But according to the Czech code employers ought to create "conditions enabling the social workers employed by them to accept and apply obligations implied by the code". ${ }^{40}$

\title{
Conclusion
}

The social worker's ability to act autonomously derives from forming a firm own identity based on self-knowledge and identification with the professional identity or organization mission. All the above mentioned aspects more or less affect the social workers' possibilities of interiorizing professional values (and together with that the mission of the profession or organization) and being guided by them in their practice. The social worker is thus rather forced to act intuitively, be guided by his own values which he confuses with professional values, or he stylizes himself in the position of an administrative worker. Nonetheless, the International Code transfers the responsibility of ethical acting to the workers, who undertake to make "ethically grounded decisions" ${ }^{41}$ A problem is that in no ethical code associations ask why workers do not succeed in observing the stipulated values. That is why it would be suitable to newly include not only in the Ethical Code of the Association of Social Workers CR some principles of the social worker's relationship to professional values, but also emphasize own reflection. The helper according to Kopriva should be "prepared at all times to perceive and accept his imperfection, weakness and vulnerability, which helping makes manifest, and by means of self-reflection and supervision facilitate development to a state better than the present one." ${ }^{42}$

\section{The Issue of Applying Professional Values in Social Work}

\begin{abstract}
The article is based on reflecting the research of Grant Agency of the University of South Bohemia no. $117 / 2013 / \mathrm{H}$, part of which was also the topic of professional values. The results of the survey research draw attention to the issue of applying professional values in social work. This article aims primarily to highlight some of the barriers to value application, mainly related to the definition of the concept of values and to the plurality of values in social work. It is based on the general notion that in their practice social workers need to follow values leading to fulfilling the mission and purpose of social work.
\end{abstract}

Keywords: social work, value, professional values, applying values

39 Mirka NEČASOVÁ, Profesní etika, p. 43.

40 (C) Společnost sociálních pracovníků ČR, Etický kodex společnosti sociálních pracovníků ČR, art. 2.2.2.

41 (C) Společnost sociálních pracovníků ČR, Etika sociální práce-principy, art. 5.

42 Karel KOPŘIVA, Lidský vฉtah jako sončást profese: Psychoterapentické kapitoly pro sociální, pedagogické a zdravotnické profese, Praha: Portál, 1997, p. 91. 


\section{Contact}

\section{Mgr. Bc. Monika Flídrová}

Univeritsy of Souht Bohemia, České Budějovice

Faculty of Theology, Department of Ethics, Psychology and Charity Work Kněžská 8, 37001 České Budějovice

monikaflidrova@seznam.cz 